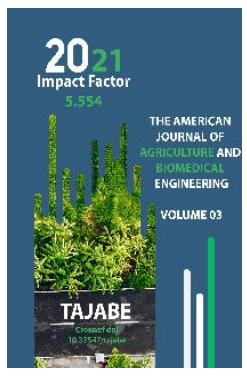

Journal Website: http://theamericanjour nals.com/index.php/taj abe

Copyright: Original content from this work may be used under the terms of the creative commons attributes

\section{The Dependence Of The Yield Indicators Of Wine Grape Varieties On The Load Of The Bush}

Fayziev Jamoliddin Nasirovich

Professor Of The Department Of Fruit And Viticulture, Tashkent State Agrarian University, Tashkent, Uzbekistan

Qurbonova Sarvinoz Anvar Qizi

Master's Degree In Viticulture And Primary Grape Processing At Tashkent State Agrarian University, Tashkent, Uzbekistan

\title{
ABSTRACT
}

The article examines the dependence of the yield indicators of wine varieties of grapes on the load on the vine. Low or excessive loading of the tubers has been found to adversely affect the subsequent growth and development of the tubers. In the variant with a load of 80 buds in the Maysky cherniy variety, the highest number of buds was recorded - 65.5\%. In the Bayan Shirey variety, the number of buds that grew when the load was 80 was the highest $-74.1 \%$, while when the load was increased (120 and 160) it was 68.2 and 59.5\%, respectively.

\section{KEYWORDS}

Grapes, wine, sort, fertileness, productivity indicators, bush load, harvested branches, buds, developing rod.

\section{INTRODUCTION}

In recent years, the Republic of Uzbekistan has been taking comprehensive measures to develop optimal agro-technologies for the production of high-quality and high-quality grapes. However, the improvement of agrotechnical measures used in viticulture, depending on the soil and climatic conditions of each region, will further increase the productivity of the viticulture sector. High efficiency can be achieved through the fullest possible use of all the factors that determine the quantity and quality of grape wine varieties. Given the importance of vine loading in the formation of grape yields, the purpose of the study is to determine the optimal amount of bud load on the vine, to study the possibility of more complete use of vines [8]. 
A.M.Negrul [2], A.S.Merjanian [6], P.P.Buzin [7] and others point out that insufficient loading on the vine leads to a violation of the correlation between the surface of the branch and its roots, the yield of emerging buds and found to lead to a decrease in productivity.

In the experiments conducted by P.P.Buzin [7] and others in Crimea, A.I.Tseyko [3] and others in the conditions of Uzbekistan, the lack of nutrients and the number of heads of grapes, which are quickly assimilated by a large number of vegetative organs as a result of overloading the vines has been shown to lead to a worsening of the conditions of formation and maturation of fruiting buds.

\section{MATERIALS AND METHODS}

Field experiments are carried out in the vineyard collection and experimental fields of the enterprise Kibray "Sharob" LLC of the Research Institute of Horticulture, Viticulture and Enology named after Academician $M$. Mirzaev, located in Kibray district of Tashkent region. "Maps of agricultural cultivation technology (2016)" of the Ministry of Agriculture of the Republic of Uzbekistan,
"Methodology of field opita" by B.A. Dospekhov (1985), H.Ch. Buriev and others [4], M.A. Lazarevsky [5] is based on methods, sources, recommendations, guidelines, and methods. Prospective wine varieties are selected from the varieties in a separate vine collection according to the recommended methodology for each experiment. In the field experiments, experiments are carried out on the norms of 4 vine bushes of Maysky cherniy and Bayan Shirey varieties.

\section{RESULTS AND DISCUSSION}

Analyzes show that the growth of vine buds varied significantly depending on the load. Consequently, in the variant with a load of 80 buds in the Maysky cherniy variety, the highest number of buds was recorded $-65.5 \%$. As the load increased, the number of growing buds decreased, $62.1 \%$ in 120 buds and $57.2 \%$ in 160 buds, respectively. The same situation was noted in the Bayan Shirey variety. At the same time, when the load was 80 buds, the number of sprouts was the highest $-74.1 \%$, while when the load was increased (120 and 160), it was 68.2 and $59.5 \%$, respectively (Table 1 ).

Table 1. Influence of load on the growth of vine buds, 2017-2019

\begin{tabular}{|c|c|c|c|c|c|c|c|c|c|}
\hline \multirow{2}{*}{ Varieties } & loading & \multicolumn{7}{|c|}{ Growth of buds at the base of fruiting branches, \% } \\
\cline { 2 - 10 } & & 1 & 2 & 3 & 4 & 5 & 6 & 7 & $\begin{array}{c}\text { The average } \\
\text { load on the } \\
\text { bush }\end{array}$ \\
\hline \multirow{2}{*}{$\begin{array}{c}\text { Mayskiy } \\
\text { cherniy }\end{array}$} & 80 & 24,5 & 38,7 & 65,9 & 79,8 & 86,7 & 68,7 & 94,3 & $65,5 \pm 1,5$ \\
\cline { 2 - 10 } & 120 & 21,8 & 34,4 & 58,0 & 69,3 & 78,5 & 83,4 & 89,5 & $62,1 \pm 1,3$ \\
\cline { 2 - 10 } & 160 & 19,9 & 28,4 & 51,7 & 64,3 & 73,8 & 79,8 & 82,6 & $57,2 \pm 1,7$ \\
\hline Bayan shirey & 80 & 36,4 & 48,3 & 68,9 & 83,4 & 91,9 & 93,6 & 95,5 & $74,0 \pm 1,4$ \\
\cline { 2 - 10 } & 120 & 28,1 & 32,5 & 57,3 & 72,6 & 83,7 & 89,4 & 93,3 & $65,3 \pm 1,4$ \\
\cline { 2 - 9 } & 160 & 21,7 & 23,6 & 48,3 & 69,7 & 75,6 & 83,1 & 89,4 & $58,8 \pm 1,5$ \\
\hline
\end{tabular}


In the analysis of the materials of the following years, different results were obtained, i.e., the number of harvested branches increased in all experimental variants as the load on the vine stem increased. This, in turn, was characterized by the fact that when the bush load is moderate (120 buds), the branches of the Maysky cherniy variety develop faster and form a large part of the leaf surface, which provides an increase in photosynthesis. As a result, the nutrition and growth of the bushes, the development of the root system and their uptake of nutrients from the soil are improved. In general, the conditions for the formation of the majority of fruiting branches have improved. The analysis showed that in the Maysky cherniy variety of grapes, when the bud load was 120, the highest number of fruiting branches was recorded $-65.8 \%$.

The minimum number of yielding branches $57.8 \%$ was determined when the load was increased to 160 buds. When the load was 80 buds, the number of fruiting branches took an intermediate position and was $61.4 \%$. This was confirmed by an increase in the coefficient of yield in the bush, as well as the coefficient of yield of fruit-bearing branches. In other words, the coefficient of fruiting branches in the bush and the coefficient of yield of fruiting branches in the Maysky cherniy variety were the highest when the bud load was $120-1.27$ and 0.82, respectively. The smallest coefficients - 1.21 and 0.72 - were determined when the load was increased to 160 buds. When the load was 80 buds, this coefficient was intermediate and was 1.22 and 0.74 , respectively.

A similar trend was noted in the Bayan Shirey variety. Consequently, when the bud load was 120 , the maximum number of fruiting branches in this variety was $36.3 \%$. The minimum number of fruiting branches - 35.5\% was determined when the load was increased to 160 buds. When the load was 80 buds, the amount of harvested branches took an intermediate place and amounted to $36.1 \%$. In the Bayan Shirey variety, the coefficient of yielding twigs in the bush and the yield coefficient of the yielding twigs were the highest when the bud load was $120-1.08$ and 0.38 , respectively. In the Maysky cherniy variety, the coefficient of yielding branches in the bush and the yield coefficient of the yielding branches were highest when the bud load was $120-1.08$ and 0.38 , respectively. The smallest coefficients - 1.04 and 0.35 - were recorded when the load was increased to 160 buds. When the load was 80 buds, the yield coefficient of the bush in this variety, as well as the yield coefficient of the yielding branches, took an intermediate position and were 1.07 and 0.37 , respectively (Table 2 ).

Table 2. Impact of bush load on current growth and productivity, 2017-2019

\begin{tabular}{|c|c|c|c|c|c|c|c|}
\hline \multirow[b]{2}{*}{ Varieties } & \multirow{2}{*}{$\begin{array}{l}\text { Loading } \\
\text { of buds } \\
\text { on the } \\
\text { bush }\end{array}$} & \multicolumn{2}{|c|}{$\begin{array}{c}\text { The amount of } \\
\text { developing branches }\end{array}$} & \multicolumn{2}{|c|}{$\begin{array}{l}\text { Including the amount } \\
\text { of fruiting branches }\end{array}$} & \multicolumn{2}{|c|}{ Coefficient } \\
\hline & & $M \pm M$ & $\begin{array}{c}\text { Loading } \\
\%\end{array}$ & $M \pm M$ & $\begin{array}{c}\text { amount } \\
\text { of twigs, } \\
\%\end{array}$ & $\begin{array}{l}\text { harvest } \\
\text { branches }\end{array}$ & $\begin{array}{c}\text { branches } \\
\text { in the } \\
\text { Bush }\end{array}$ \\
\hline
\end{tabular}


The American Journal of Agriculture and Boimedical Engineering (ISSN - 2689-1018)

\begin{tabular}{|c|c|c|c|c|c|c|c|}
\hline \multirow{2}{*}{$\begin{array}{c}\text { Mayskiy } \\
\text { cherniy }\end{array}$} & 80 & $43,8 \pm 1,2$ & 67,3 & $26,7 \pm 1,2$ & 61,4 & 1,22 & 0,74 \\
\cline { 2 - 8 } & 160 & $61,9 \pm 1,6$ & 61,1 & $39,9 \pm 1,1$ & 65,8 & 1,27 & 0,82 \\
\hline & $72,8 \pm 1,5$ & 57,3 & $43,1 \pm 1,2$ & 57,8 & 1,21 & 0,72 \\
\hline EKF $_{05}$ & & 0,3 & & 0,7 & & & \\
\hline \multirow{2}{*}{$\begin{array}{c}\text { Bx } \\
\text { shirey }\end{array}$} & 80 & $56,1 \pm 1,8$ & 70,1 & $20,5 \pm 1,1$ & 36,1 & 1,07 & 0,37 \\
\cline { 2 - 8 } & 120 & $77,9 \pm 1,2$ & 64,1 & $28,3 \pm 0,9$ & 36,3 & 1,08 & 0,38 \\
\hline EKF $_{05}$ & & $92,7 \pm 1,3$ & 57,5 & $32,4 \pm 0,9$ & 35,5 & 1,04 & 0,35 \\
\hline Sx & & 0,7 & & 1,1 & & & \\
\hline
\end{tabular}

According to Professor A.M.Negrul [1], grapes are a perennial plant, and the annual harvest requires a certain amount of nutrients from the plant. The nutrients consumed in the crop can lead to a significant decrease in the strength of the vine bushes. Also, when pruning against the background of high agronomic techniques, insufficient supply of buds and yield load on the vine bushes leads to the budding of some individual branches. In vine bushes that are not provided with sufficient loads, there is a tendency for budding growth without the development of productive buds. Otherwise, overloading and when the agrophone is low will result in a large but poor quality yield of the vine bush. Due to the weakening of the vines, the vines are small and the branches grow weakly. The following year, the conditions for the formation and yield of buds will decrease. Weak twigs with insufficient assimilation surface cannot even supply their vine heads with photosynthesis process products and do not have the strength to send them to the twig to strengthen their common buds.

\section{CONCLUSION}

It has been studied that the yield of grape wine Maysky cherniy and Bayan shirey varieties depends on the root load. In the Maysky cherniy variety, the bud load was the highest at $120-1.27$ and 0.82 , respectively. The smallest coefficients - 1.21 and 0.72 - were determined when the load was increased to 160 buds. A similar trend was noted in the Bayan Shirey variety. Consequently, when the bud load was 120 , the maximum number of fruiting branches in this variety was $36.3 \%$. The minimum number of fruiting branches - 35.5\% was determined when the load was increased to 160 buds.

\section{REFERENCES}

1. Negrul, A.M. (1955). Results of the discussion on problematic issues. Winemaking and viticulture of the USSR, (2), 21-26.

2. Negrul, A.M. (1967). On the optimal load of grape bushes. Winemaking and viticulture of the USSR, (5).

3. Tseiko, A.I. (1962). Agrotechnical method of planning yields in fruiting vineyards. Questions of viticulture and winemaking, 147. 
4. Buriev X.Ch., Enileev N.Sh. \& at all. (2014). Methods of calculations and phenological observations in experiments with fruit and berry plants. T. $64 \mathrm{p}$.

5. Lazarevsky, M.A. (1946). Methods of botanical description and agrobiological study of grape varieties. Ampelography USSR, 1 (1946), 347.

6. Lyashenko, G.V., \& Marinin, E.I. (2014). Model of the probability of frost damage to grapes of various varieties on the territory of the Odessa region. Ukrainian Hydrometeorological Journal, 14, 123-128.

7. P.P. Buzin (1956). Biological bases of grape culture. Viticulture in Uzbekistan. Tashkent. pp. 78-79.

8. Fayziev J.N. (2020). Scientific substantiation of technology to increase the yield and quality of seedless varieties of grapes in Uzbekistan. Doc. diss. avtoref. Tashkent. pp.154-164. 